"Major challenges to sustainable enterprise development within the tourism industry in Libreville, Gabon"

$\begin{array}{ll} & \text { Elsa-Olivia Moussavou } \\ \text { Robertson K. Tengeh } \\ \text { Chris Cupido }\end{array}$

Elsa-Olivia Moussavou, Robertson K. Tengeh and Chris Cupido (2016). Major ARTICLE INFO challenges to sustainable enterprise development within the tourism industry in Libreville, Gabon. Problems and Perspectives in Management, 14(4), 103-111. doi:10.21511/ppm.14(4).2016.13

DOI http://dx.doi.org/10.21511/ppm.14(4).2016.13

RELEASED ON Wednesday, 14 December 2016

JOURNAL "Problems and Perspectives in Management"

FOUNDER LLC "Consulting Publishing Company "Business Perspectives"

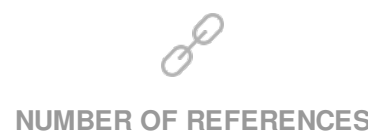

0
NUMBER OF FIGURES

0

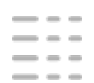

NUMBER OF TABLES

0

(C) The author(s) 2023. This publication is an open access article. 
Elsa-Olivia Moussavou (South Africa), Robertson K. Tengeh (South Africa), Chris Cupido (South Africa)

\title{
Major challenges to sustainable enterprise development within the tourism industry in Libreville, Gabon
}

\begin{abstract}
SMMEs provide an indispensable framework for addressing unemployment, poverty and boosting the economy of a country. This report was impelled by the need to create and sustain enterprises within the hotels and restaurant subsector of the tourism industry in Libreville, Gabon. A quantitative methodology was embraced to disperse seventy selfadministered questionnaires to owners and managers of hotels and restaurants. The results demonstrate that the key components which lead to the failure or non-sustainability of businesses include: limited access to start-up finance required to cover start-up and growth cost, the low return on investment, as well as the mismanagement of businesses. Given that job creation remains a dependable method for diminishing unemployment and poverty, establishing and sustaining businesses in Libreville would be a step in the right direction in Gabon.
\end{abstract}

Keywords: venture creation, enterprise development, entrepreneurship challenges, Libreville.

JEL Classification: M13, L26, L83.

\section{Introduction}

Notwithstanding the numerous years of extraordinary economic advances for countless people around the world, unemployment, poverty and inequality linger as a critical hurdle to sustainable development and global stability. Though multinational companies have created supply chains spanning the globe, there is a pervasive opinion that the benefits are not mutually shared by the host, producer countries and communities (ILO, 2014). In fact, there is an urgency to improve on the quality and number of jobs created in most countries if social cohesion, broad-based wellbeing and reduce poverty is to be achieved and maintained (ILO, 2014).

Entrepreneurial activities are universally recognized as one of the best initiatives to accomplish the preceding objective. This aside, the support that entrepreneurship development enjoys today, depends on the context. For example, entrepreneurship is encouraged by the government that understands its spin-offs in terms of growth, innovation, employment and poverty reduction (Stokes et al., 2010). In Gabon, small, medium and micro size enterprises (SMMEs) are recognized for their capacity to create jobs in the private sector and contribution to the GDP and economy of Gabon (Boudiala Boudiala, 2011).

While it has been observed that the majority of the economically active population in Libreville are employed by SMMEs, it is discerning to note that Libreville remains a city with a relatively high level of poverty and failed businesses (Boudiala Boudiala, 2011). Business failure is assumed at the point of

(c) Elsa-Olivia Moussavou, Robertson K Tengeh, Chris Cupido, 2016. Elsa-Olivia Moussavou, Faculty of Business and Management Sciences, Cape Peninsula University of Technology, South Africa.

Robertson K Tengeh, Faculty of Business and Management Sciences, Cape Peninsula University of Technology, South Africa.

Chris Cupido, Faculty of Business and Management Sciences, Cape Peninsula University of Technology, South Africa. insolvency and when the business is unable to carry on trading (April, 2005). This is the point at which the entrepreneur finds himself or herself in deep trouble. April (2005) categorizes the factors that may lead to business failure to include: a lack of skills, a lack of management skills, indigent financial control and lack of accounting knowledge, credit problems, inattention to marketing, ignoring the human factor, failure to develop a strategic plan, uncontrolled growth or managing growth, mediocre location, incorrect pricing, failure to adapt to the changing needs of the enterprise, and poor time management. The most common mistakes of owners of restaurants and hotels are the inability to manage the venture's cash flow, the lack of proper financial management, and a failure to deal with the management of the business generally. A successful entrepreneur should be in possession of a sound knowledge of the company. To this end, Kumar (2008) counsels that an entrepreneur must have a number of attributes and skills to plan properly and make a success of an enterprise, especially during the initial stages.

Though highly detested, failure is a double-sided sword. While it leaves some scarred for life, for others it serves as a learning curve (Stokes et al., 2010). Hence, the latter, consider that in failing, they understand how best to run a business. For them, the problem is not necessarily the lack of any particular skill, but simply not being able to face and manage a multitude of problems demanding attention simultaneously. The challenge is to have the experience and understanding necessary to know how to prioritize problems.

Evidence from a number of countries suggests that when supported by government, SMMEs may survive to carry on the legacy of creating jobs and reducing poverty (Cupido, 2002). As such, Gabon has emerged as one of the countries in which entrepreneurial activities have been acknowledged by the government. 
The government of Gabon has made resolute efforts to increase transparency in the attempt to brand the country attractive for internal investments to boost the economy. In addition, the current government is trying hard to encourage entrepreneurial growth through venture creation and development, in order to alleviate unemployment and poverty.

Historically heavily dependent on oil, the Gabonese government in recent years encouraged entrepreneurship in an attempt to relieve the economy from this dependence. Though over three thousand new ventures are registered every year, only a few survive (Boudiala Boudiala, 2011). This translates to potential jobs and opportunities lost by the community. It is against this background that, although many would-be entrepreneurs are able to perceive and exploit opportunities; organize all the necessary resources to set up a business with the aim of success; some of them shine and excel, while others struggle and fail.

Hoping to minimize the associated problems, the Gabonese government with the support of companies such as Promo Gabon, Ministere des Petites et Moyenne Entreprises et du Commerce et de L'Artisanat (PME) (the "Ministry of SMMEs") made conjunctive efforts to provide assistance to entrepreneurs with regards to the creation and development of enterprises. However, current statistics indicate that a considerable proportion of these enterprises fail. This could be ascribed to factors including: limited access to finance, inadequate management skills, lack of education, poor marketing and entrepreneurial knowledge. The foregoing supposition prompted the need to identify and analyze the key challenges that entrepreneurs encounter in venture creation and development in Gabon.

\section{Literature review}

1.1. Overview of entrepreneurship. As a multidimensional concept that impacts on economic performance (Carree \& Thurick, 2002) a number of definitions of entrepreneurship abound. Entrepreneurship is the noticeable willingness and ability of persons, on their own, in groups, outside and inside existing companies, to create and recognize new economic opportunities and to transform these into goods and service for which there is a demand (Wennekers \& Thurik, 1999). From an etymological perspective, the word "entrepreneurship" stems from "entreprendre" which means to pursue; to undertake opportunities; to fulfil wants and needs through starting businesses and innovation (Burch, 1986).

1.2. Venture creation. Timmons (1999) describes venture creation as the raw start-up of a business, the entrepreneurial thinking that breaks ground for businesses. Entrepreneurial success is essential for success in the venture creation process. In support of this view, McIntyre and Alon (2005) note that success in entrepreneurship usually involves building a team of people with complementary skills and talents, and sensing an opportunity, where others see only contradiction, chaos and confusion. Kurakto and Hodgetts (2007) maintain that venture creation consists of activities associated with the initial formulation of the venture. It is the foundation of the entrepreneurial process and requires creativity and assessment.

1.2.1. Challenges in venture creation. Hatten (2015) holds that starting a business from the ground up is more difficult than buying an existing business or a franchise, because nothing is in place. Though the essence of entrepreneurship, for many people, the process of taking an idea through all the steps, time, money and energy needed to become a viable business is a daunting task (Hatten, 2015). Besides, the risk is concomitantly higher when starting a business from scratch.

Barrow et al. (2005) insist that the first thing one needs is a business idea that is clear, feasible and provide necessary and detailed information about the proposed business. This is what a well written business plan captures and is meant to achieve. Barrow et al. (2005) add that one key reason to produce a business plan is to try to avoid, as much as possible, the mistakes that others have already made. The challenges that entrepreneurs encounter during business start-up are not limited to the following:

1.2.1.1. No management of accounts. Cash management is only one aspect of the financial information that an owner needs to remain in control of the business. Profit and loss accounts, a balance sheet and key performance ratios such as gross margin, debtors' days and stock turnover all have a part to play in a prudent and well-run business. It is not merely useful to understand the basics of accounting; for company directors, it is a legal requirement (Barrow et al., 2005).

1.2.1.2. Poor financial management control. Financial management control has a strong influence on the livelihood of a company. Poor financial management is a major reason why businesses fail. Barrow et al. (2005) argue that owner-managers often leave financial questions to their accountants to sort out at year-end. It would be a mistake to concentrate on the production of goods and services or attracting more clientele without regularly checking on the financial health of the company. Barrow et al. (2005) agree that, by the time the set of figures is produced, perhaps up to 18 months have elapsed, and the financial disturbance is pronounce making failure inevitable. This could, of course, have been easily prevented with a modicum of outside help and advice. 
1.2.1.3. Poor relationships. One of the hidden reasons for early stage business failure is a poor connection between business allies. Business partners are meant to work together harmoniously and to trust each other, so that the business may attain its goals. Indeed, business partners need to be temperamentally suited, have complementary skills and be prepared to compromize without falling out. The selection of a business partner should always be done according to the best interests of the company. The majority of successful associations tend to build a relationship before working together, preferably as allies rather than just as friends.

1.2.1.4. Managing debt. Blanchard (2011) mentions that Henry Ford is alleged to have said that he must be rich, because he owes everyone money. Most entrepreneurs see the humour in this, because they know debt is a burden for a new business. Debt makes successful entrepreneurs nervous. Even those who are most successful lie awake at night worrying about it. The problem with borrowing money is that it has to be paid back and the sooner this happens, the better off you and your business will be. If you are not concerned about how much you owe to banks, credit cards, private lenders, vendors, as well as yourself, then you are jeopardizing the creation of personal wealth through a successful business. On the one hand, while nobody likes jangled nerves, on the other hand, anxiety over debt can be a positive force if it motivates you to manage your business from the very beginning so as to minimize debt.

1.2.1.5. Limited access to finance. According to Kauffmann (2005), SMMEs' main sources of capital are their retained earnings, informal savings and loan associations (tontines). These are unpredictable, not very secure and have little scope for risk sharing because of their regional or sectoral focus. Wickham (2004) argues that many entrepreneurs complain about the "funding gap" which refers to an inability to get hold of capital to support their ventures. Whatever its source, the funding gap presents problems to entrepreneurs, to investors, and to the wider world that benefits from entrepreneurial activities (Wickham, 2004).

1.2.1.6. Lack of education. There is considerable evidence to suggest that enterprises started by people who are well educated are generally more successful. Thus, education can serve to decrease the failure rate of new business (Co et al., 2006). Though there are successful isolated cases of entrepreneurs with limited or no schooling, there is no doubt that education can definitely play an important role in the success or failure of a business. Co et al. (2006) add that being educated is not a necessary requirement to create a new venture, but it does help an entrepreneur to solve problems within the business. For instance, the entrepreneur will have to solve problems relating to finance, marketing, human resources and general management of the business, and may have to acquire skills in these areas.

\subsubsection{Lack of management skills and training.} General management skills are required to organize the physical and financial resources needed to run the venture, and people management skills are needed to obtain the necessary support from others for the venture to succeed (Wickham, 2004). According to Co et al. (2006), entrepreneurs need to be equipped with a variety of skills, since proper management skills have to be applied within a company. Wickham (2004) proposes the following as important general business management skills: strategy, planning, marketing, financial, project management, and time management skills.

Training in a business has a positive impact on the employer, the employee and the whole company. According to Walker and Miller (2010), training simply means teaching people how to do their job. Training is not a stand-alone entity, but one of several elements that make for organizational effectiveness (Walker \& Miller, 2010).

1.2.1.8. Poor business plan. Dlabay et al. (2009) identify the key features of a business plan and argue that they provide a general description of the company, the credentials of the owner, a description of the product and service, an analysis of the market (demand, customers and competition), and a financial plan. Entrepreneurs find it very difficult to raise capital from financial institutions without a business plan, something that they sometimes confuse with the actual creation of a venture. Financial institutions customarily peruse the business plan for flaws and use this as the basis for the rejection funding applications (Nieman \& Nieuwenhuizen, 2013).

1.2.1.9. Inadequate market research. The problems addressed during forecasting may resurface if the entrepreneur does not conduct a proper study of the market. Such an endeavour should examine, as well as understand the outcome of the market research. As such, a business person must be able to design and conduct market research. It will help the entrepreneur to identify external threats to the business and when and where to pursue an opportunity. The ability to discover and understand the competition data is very important for the company to gain a competitive advantage. Hence, market research is imperative for the business' survival and growth. In this light, Malhotra and Birks (2003) claim that market research enables the entrepreneur to ascertain and manage customers' needs.

1.3. Enterprise development. According to Bolton (1997), enterprise development is the generation and 
progression of new enterprises. Cassidy and Madzwamuse (1999) argue that enterprise development has to be sustainable, focusing on marketing and profitability, equity, and the enhancement of livelihood.

1.3.1. Challenges to enterprise development. It is relevant to mention that the challenges of venture creation listed above are also applicable to enterprise development (lack of management skills, lack of education, restricted access to finance, and managing debt, falling out, poor financial management control, no management accounts, and electricity supply issues). These challenges are deemed to impact on the subsequent growth of the business.

Besides the foregoing, Barrow et al. (2005) distinguished three sets of challenges for enterprise development as: the challenges of getting into a business; the challenges of growing the business; and the challenges of deciding whether to re-invest or exit. Barrow et al. (2005) believe that good preparation and planning is a significant advantage in dealing with each of these sets of challenges. And from this planning perspective, it is also clear that each of the three sets of challenges corresponds to a distinct business planning requirement, each of them designed to cope with quite different problems; thus, a business plan to minimize start-up risks, then, a strategic growth plan and, finally, an exit plan.

In terms of the business cycle, enterprise development involves trying to survive the introductory stage of a business to reach the growth stage. In effect, an entrepreneur will need a strategic plan to make the business grow by properly following its vision and mission. According to Matthews and Dennis (2003), to build a strong, growth-oriented company, a good idea is just the beginning. A leader needs to create a clear mission and a culture to support that mission, to build a solid infrastructure and hire the right people. Failure to address any of those factors could not only mean failure to grow, but it could also prevent the creation of any value in the company. Barringer and Ireland (2008) caution that growth is a double-edged sword in that it can threaten the stability of a firm's operation in every area, from human resources to finance, if not managed properly.

\section{Materials and methods}

2.1. Research design. The quantitative method was employed in this study, through the delivery of questionnaires to identified business owners. The quantitative method entails the collection of numerical data, exhibits a view of the relationship between theory and research as deductive, has a predilection for the natural science approach (and for positivism in particular), and embraces an objectivist conception of social reality (Bryman \& Bell, 2011).
A descriptive study attempts to describe systematically a situation, problem, phenomenon, service or programe, or provides information about the case (Kumar, 2014). This study meets this criterion in that it seeks to understand how hotels and restaurants created and developed in Libreville, Gabon.

\subsubsection{Description of the research population.} According to Haralambos (2005), the term population refers to any group of individuals who have one or more characteristics in common that are of interest to the researcher. The research population in this study was limited to all the owners of hotel and restaurant businesses in Libreville. As such, Gabonese or local entrepreneurs, and foreign entrepreneurs running businesses in Libreville were included.

2.1.2. Sampling technique and sample size. According to Bouma and Ling (1999), sampling is an important feature of all research. The basic idea of sampling is that by selecting some elements within a population, we may draw conclusions about the entire population (Cooper \& Schindler, 2003). For this study, the snowballing technique was employed - a form of nonprobability sampling.

Businesses that were chosen had to be three years or older, the reason being that if the company had managed to survive that long, it was reasonable to infer that proper successful strategies might have been applied (Nieman \& Nieuwenhuizen, 2009, Tengeh et al., 2011). Utilizing the snowballing procedure, these researchers initially identified an appropriate person from the sample and, then, got that person to draw other suitable people into the research (Tengeh et al., 2011). This approach introduces an unplanned positive aspect to the research in that the participation of the interviewee is facilitated by the referral of a friend (McDonald et al., 1999).

The snowballing technique was particularly relevant for this study given standard constraints and those peculiar to Gabon. The Gabonese infrastructure is still being developed so it was difficult for the respondent to identify hotels and restaurants in the absence of street names. The technique was very effective, saving the researcher from unnecessary driving around, and was, therefore, applied all the way. One of the difficulties lay in actually making contact with the business owner, as some of them were unavailable, too busy or not even in the country. So when the researcher struggled to track down entrepreneurs, she had to find alternative ways of getting face-to-face interviews in the limited time available. That was when the snowballing sampling technique played an important role.

The sample for this study consisted of 70 respondents. The Ministry of SME, Art and Commerce (Le Ministere de PME de l'Artisanat et du 
Commerce) deals with enterprises from various sectors of industry in Libreville, including the hospitality industry. This sector comprised 1076 hotels and restaurants in the year 2011 (Boudiala Boudiala, 2011). This report was the most recent at the time of data collection. How large a sample should be is a function of the population parameters under study and the precision of estimation on the part of the researcher (Cooper \& Schindler, 2003).

According to the Raosoft Sample Size Calculator and Survey Monkey, 5-10\% is the typical margin of error that is tolerated for a proper study, with a level of confidence of above $90 \%$. Working with Boudiala Boudiala's (2011) estimate of 1076 firms, an error margin of $10 \%$ and confidence level of $90 \%$ the plausible sample size of 64 participants was deemed sufficient. To improve on the validity of the study, a much higher sample size of 74 was utilized. The final composition of the sample was: 69 business owners/entrepreneurs and 5 Gabonese citizens or employees. This sample was, however, reduced to the 70 participants who could be reached at the time of data collection.

2.1.3. Data collection and analysis. Most methods of data collection can be used across studies whether classified as qualitative, quantitative or mixed method (Kumar, 2014). This study employed questionnaires for the collection of data.

A questionnaire is one of the numerous ways of soliciting information from participants, usually by posting direct or indirect questions (Gillham, 2007). According to Cameron and Price (2009), questionnaires allow the researcher to gather data relatively cheaply from a large group of people. It also allows the researcher to integrate the collection of quantitative and qualitative data through one means of data gathering.

For data collection in this study, some questionnaires were dropped off and later picked up by the researcher. Hence, the respondents had the chance to read the questions, interpret what is expected and, then, write down their answers (Kumar, 2014) without any pressure from the researcher. The questionnaire was designed in an interactive style so the respondents could feel as if someone was talking to them. Other questionnaires were completed by the participants in the presence of the researcher and it is believed that this cohort of respondents benefited from the interaction in the form of motivation and clarifications.

2.2. Data analysis. Information is examined by filtering it from one's primary and secondary sources (Brynard \& Hanekom, 2006). This process is intended to uphold facts and discard immaterial information. These facts are, then, used to answer the research question. In this study, the most important means of collecting information was the survey questionnaire. The SPSS statistical package was utilized to analyze and descriptive statistics (via graphs or charts) was the preferred output.

\section{Results and discussion}

The outcomes are presented in (pie) charts and, then, followed by analysis and discussions.

3.1. Gender of the sampled population. Figure 1 indicates ownership in terms of gender. It was noted that $44 \%$ of the sample comprised women entrepreneurs, with the majority of $56 \%$ being male entrepreneurs. While the research indicates that male entrepreneurs are more active than women, it, nonetheless highlights the progress made in terms of equity given that there is a close match between men and women. This indicates the concerted efforts made by women to be financially independent.

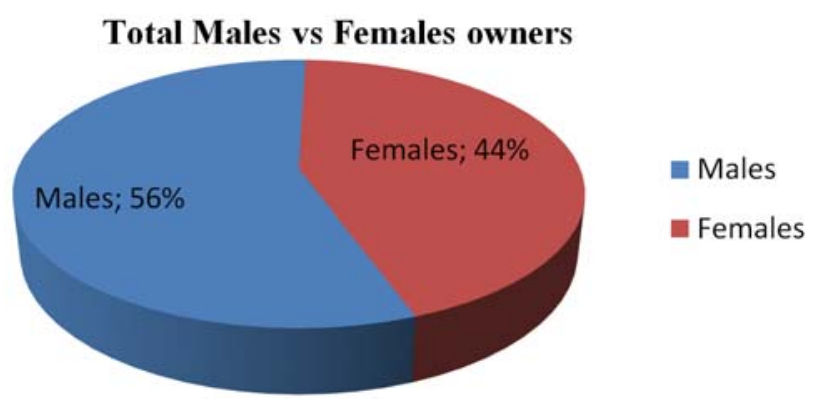

Fig. 1. Gender of sampled population

The finding reflected in Figure 1 is consistent and comparable with Wang (2009) and Cupido (2002) who also found the majority of people starting businesses to be male. But the finding also demonstrates that despite the fact that men are dominant in that field, women are no less motivated to contribute to economic development and to provide employment opportunities not only for themselves, but also for others. A common finding is that there are more similarities than differences between male and female entrepreneurs once they have actually started the business (Mahadea \& Youngleson, 2013). Drawing on the literature review, Birley and Muzyka (2000) reported that men's performance in venture creation is aimed at financial success, while for women it is also about good employee and customer relationships. This makes women's involvement as consistent as men's in the hotel sector, because the requirements of the hospitality industry fit both men's and women's objectives.

3.2. The study of the environment. Figure 2 reveals that $58 \%$ of owners of restaurants and hotels had conducted a study of the environment before opening their businesses, while $42 \%$ had done no environmental study at all. Study of the environment plays a significant role in the establishment of a business in that it allows the 
owner to spot the presence of competition, likely customer demands and how best to formulate the appropriate strategies for differentiation and positioning.

\section{The study of the environment}

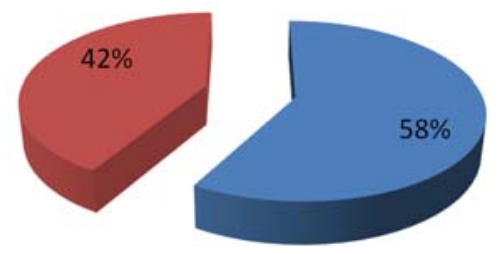

- Yes

No

Fig. 2. The study of the environment

The finding reflected in Figure 2 suggests that the majority of respondents see the importance of researching the environment during the start-up phase of the business. Pride and Ferrell (2010) explain that the market environment consists of external forces that directly and indirectly influence an organization's acquisition of inputs (human, financial, natural resources and raw materials, and information) and creation of output (goods and services, or ideas). The market environment comprises six factors: competitive, economic, political, legal and regulatory, technological and sociocultural (Pride \& Ferrell, 2010). The environmental issues mentioned by respondents in this field include:

- strong competition;

- respondents are unhappy with their current location; and

- the involvement of City Hall and Public Hygiene Institute and Sanitation (Health Ministry), since the Health Ministry ensures that enterprises provide a clean environment and that hygienic condition are maintained.

The objective of collecting environmental data was to detect and assess trends that could influence the firm or its target market, and to identify future market opportunities and potential threats.

3.3. Business plan and management training vs. no business plan and no management training. Figure 3 represents the percentages of entrepreneurs starting a business with a business plan and management training, and against those starting a business with no business plan and no training. The survey revealed that $69 \%$ of the owners of restaurants and hotels started their businesses with a business plan and formal experience, while $75 \%$ received had some management experience and training. On the other hand, $31 \%$ had no business plan and $25 \%$ had no formal management training. The results further disclosed that $67 \%$ of the sample population have experience in this type of enterprise and $33 \%$ do not.

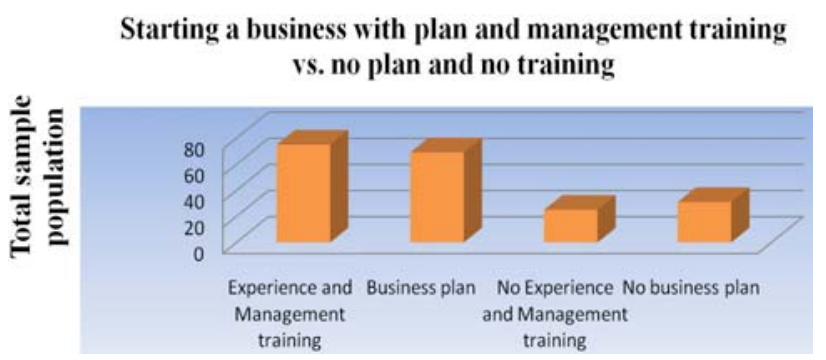

Fig. 3. Business plan and management training vs. no business plan and no management training

Analysis of the Figure 3 indicates that there are still entrepreneurs who do not consider a business plan for their businesses to be important, while this study strongly suggests the opposite. Dlabay et al. (2009) and Hisrish et al. (2010) acknowledge the significance of a business plan and emphasize that a business plan is valuable to the entrepreneur, potential investors and even new personnel who are trying to familiarize themselves with the venture, its goals and objectives. Nieman and Neuwenhuizen (2013) argue that compiling a business plan is important for obtaining funding; it also serves an internal purpose and helps to reduce risk in the venture creation process.

As far as management training is concerned, there were numbers of respondents who had had no management training. Walker and Miller (2010) believe that when an employer has not received good training, there is likely to be an atmosphere of tension and crisis and conflict all the time, because nobody is quite sure of how the various jobs are supposed to be done and who has responsibility for what.

3.4. In which department would you like to improve your company? Figure 4 indicates which department entrepreneurs would like to improve and run more effectively. The responses indicate that $23 \%$ of owners of hotels and restaurants would like to make improvements in the marketing department. About 19\% of owners would like to improve the whole venture; about $17 \%$ owners would like to make improvements in management and $15 \%$ in administration. Only $11 \%$ of owners would like to make changes in the financial department. Furthermore, only 9\% of business owners are happy with the way their businesses are running and do not want to make any changes. Finally, $6 \%$ of them would like to improve the layout of the rooms of their hotels, service quality and technical and human resources. 


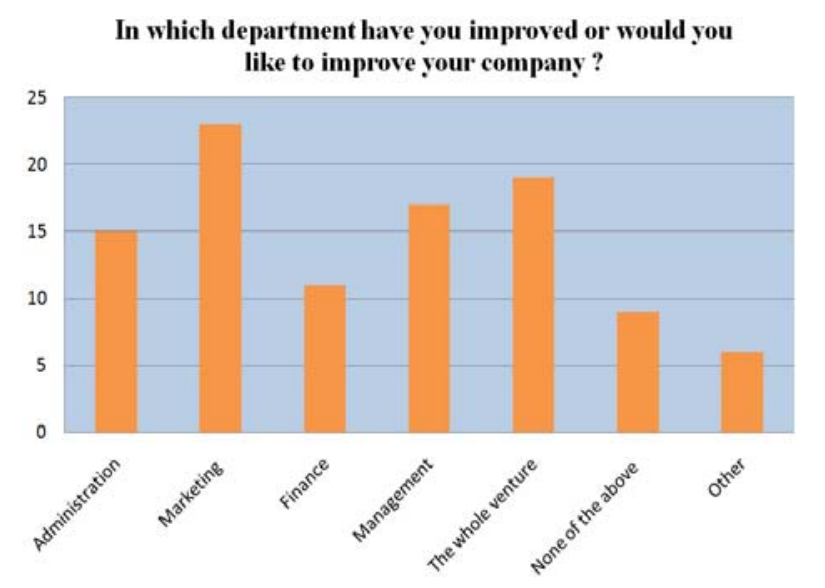

Fig. 4. Desired improvement in the company

These findings are consistent with the findings of Chu (2014) who highlights the importance in the hotel sector of each of the departments represented in Figure 4. By asking the question "in which department had you improved or would you like to improve your company?" This question aimed to link the challenges to a source department. As such it was normal for the majority of respondents $(66 \%)$ to observed obstacles in multiple departments, including: marketing; human resources; finance and technology departments. For instance:

- In the management department, the issues found included: poor management style, the struggle to cope with everyday administration.

- In the finance department, the predominant issues found were: limited access to funding and not reaching financial objectives.

- In the human resources arena: unskilled and unmotivated team, as well as their lack of training and commitment. Chon and Maier (2010) believe that the strength of the hotel and restaurant sector lies in employees' motivation level and dedication to customer service. They cite the cost of training and developing personnel as an area of concern.

- In the marketing domain, the issues found included: being unhappy with the current location, strong competition, difficulties in making customers loyal or an absence of customers, and service quality. According to Bowie and Buttle (2004), the key feature of marketing in the hotel and restaurant sector is that these businesses have an external focus and are constantly researching their customer needs and wants, their competitors, and the environment in which they operate.

- In the context of technology, $22 \%$ of the respondents pointed to access and adaptation to new technology. To this end, Enz (2010) notes that the hospitality industry faces the challenge of selecting the appropriate technologies for consumers.
3.5. Reasons for not getting financing help from the government. Figure 5 illustrates the reasons why entrepreneurs are not getting financial help from the government. The results indicate that $72 \%$ of the owners of restaurants and hotels have never asked for finance from the government. About $17 \%$ of entrepreneurs find the process of getting finance very long. 3\% of entrepreneurs have applied for finance, but were denied, while $8 \%$ of the owners gave other reasons such as: they had never thought of asking for finance; the business was sponsored by another government department; and the venture was not registered in the past.

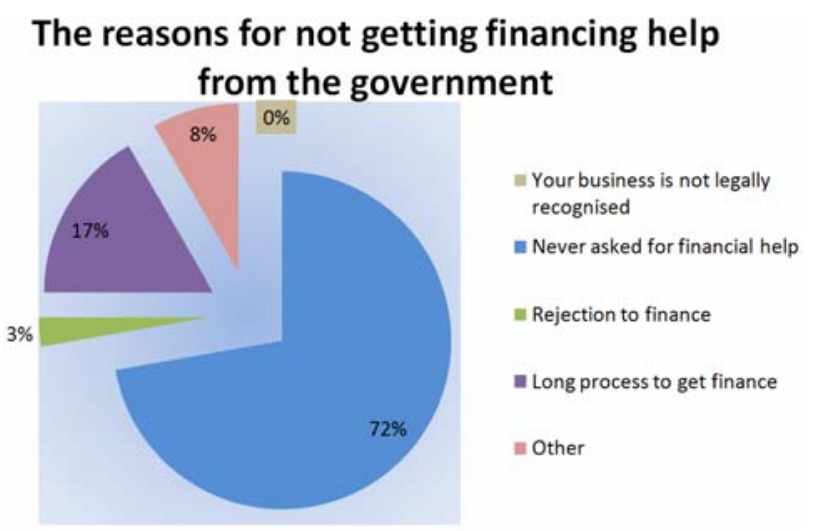

Fig. 5. Reasons for not getting financing help from the government

Cognisant of the structural deficiency in the financial system, the respondents felt the urge to depend of their own efforts to raise finance. For instance, Willy (one of the participants) noted:

"Starting and improving a business is a very challenging process with limited finance. I never asked any money from the bank or government, because the process is long, and I know they will not grant the money to me..."

Without financial resources, a new venture will not be able to obtain the vital resources necessary to exploit their business idea, no matter how good it is (Blundel \& Lockett, 2011). Edeson (2014) argues that while government support can foster the local entrepreneurs' efforts, there are funding shortages due to the changing demands for government finance and the health of the economy, constraints this effort. Nieman and Nieuwenhuizen (2013) point out that access to finance is acknowledged worldwide as being a barrier to entrepreneurship. This explains why the respondents rely mostly on their personal funds.

3.6. The company's expenses and expected sales. Figure 6 indicates the profitability of the company by showing whether expenses are higher than expected sales. The survey reveals that $47 \%$ of business owners are spending more than they are making profit, suggesting that they are not managing their finances correctly. 53\% of owners of restaurants and hotels are 
making a profit, indicating that their businesses are running properly.

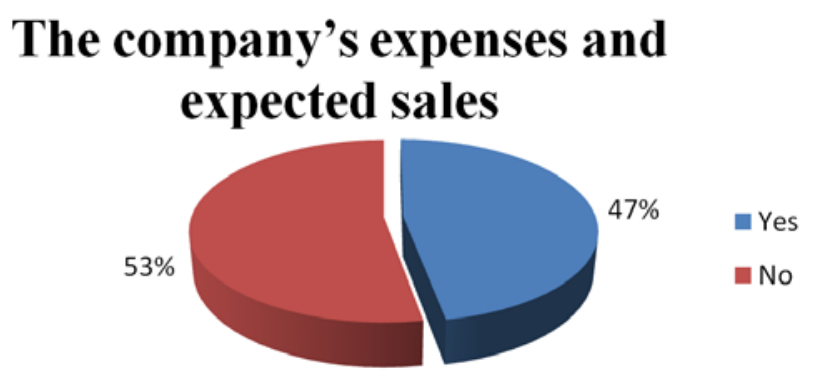

Fig. 6. The company's expenses vs. expected sales

Marx, Swardt, Smith and Erasmus (2009) agree that the medium- and long-term goal of both owner and management should be to increase the value of the firm; this can be done by investing in assets that will add value to the firm and by keeping the firm's cost of capital as low as possible. Although this finding suggests that most owners of hotels and restaurants in Gabon make normal profits, it is not clear whether these profits are sustainable. Like the majority (51\%) of participants, Claudia (owner of a hotel) commented that:

"The return on investment is still lower than our investment for the business despite the good profit we are making".

It can be said that when the return on investment does not cover the investment in the business as planned by the entrepreneur, it may indicate a business failure. For some, the firm's objective is always to maximize profit (Gitman, 2009), while others believe that it is to maximize wealth (Marx et al., 2009).

\section{Conclusion and scope for future research}

A relatively high level of poverty and unemployment have pushed many people into starting SMMEs. Given their absolute numbers and inclination to fail, one may contend that ensuring that these businesses are selfsustaining, would be the right stride towards guaranteeing economic sustainability in any economy. Thus, entrepreneurial activity may be the missing puzzle in the quest for sustainable development in a number of countries. Perhaps it was on these grounds that the Gabonese government embarked on promoting SMMEs via support initiatives. The outcome of this laudable effort has been dismal given that business failure persists, and this paper has recorded the following as significant contributors: limited access to finance from financial institutions to serve as capital for establishing a new business, and difficulties with meeting monetary objectives. Though found to possess profound entrepreneurial knowledge, additional evidence suggests that there are still challenges that impact negatively on the entrepreneur's ability to meet his or her financial objectives. Moreover, respondents pointed to challenges in the areas of management, finance, human resources, and marketing departments, as well as in the technological sphere. The significance of this paper perhaps lies in its relevance to the ongoing approach to the entrepreneurship development debate in Gabon. Because this report was limited geographically to Libreville, extending the study to the provinces of Gabon to provide a holistic picture of the hospitality industry in the country is suggested. Furthermore, comparative, cross-national studies might also be attempted.

\section{References}

1. African

Economic Outlook. (2013).

Doing business.

Available

at: http://www.africaneconomicoutlook.org/fileadmin/uploads/aeo/2013/PDF/Gabon\%20-\%20African\%20Economic \%20Outlook.pdf. Accessed on 17 December 2014.

2. Barringer, B.R. and Ireland, R.D. (2008). Entrepreneurship: successfully launching new ventures. $2^{\text {nd }}$ edition. Upper saddle River, New Jersey: Pearson Prentice Hall.

3. Barrow, C., Burke, G., Molian, D. and Brown, R. (2005). Enterprise development: the challenges of starting, growing and selling businesses. London: Thomson.

4. Birley, S. and Musyka, D.F. (2000). Mastering entrepreneurship: the complete MBA's companion in entrepreneurship. London: Pearson.

5. Blanchard, R. (2011). Creating wealth with a small business: strategies and models for entrepreneurs in the 2010s. Bloomington, IA: iUniverse.

6. Blundel, R. and Lockett, N. (2011). Exploring entrepreneurship: practices and perspectives. Oxford: Oxford University Press.

7. Bolton, W. (1997). The university handbook on enterprise development. Paris: Columbus Handbooks.

8. Boudiala Boudiala, A.K. (2011). Le fichier des petites et moyennes entreprises (FiPME). Gabon, Libreville: PME.

9. Bouma, G.D. and Ling, R. (1999). The research process. $5^{\text {th }}$ edition. New York: Oxford University Press.

10. Bowie, D. and Buttle, F. (2004). Hospitality marketing: an introduction. Oxford: Elsevier Butterworth-Heinemann.

11. Bryman, A. and Bell, E. (2011). Business research methods. $3^{\text {rd }}$ edition. New York: Oxford University Press.

12. Brynard, P.A. and Hanekom S.X. (2006). Introduction to research in management-related fields. Pretoria: Van Schaik.

13. Burch, J.G. (1986). Entrepreneurship. New York: Wiley.

14. Cameron, S. and Price, D. (2009). Business research methods: a practical approach. London: McGraw-Hill.

15. Carree, M.A. and Thurik, A.R. (2002). The impact of entrepreneurship on economic growth. Available at: http://people.few.eur.nl/thurik/Research/Books/Thurikf.pdf. Accessed on 6 January 2016. 
16. Cassidy, L. and Madzwamuse, M. (1999). Enterprise development and community-based natural resources management in Botswana. Report of Workshop Proceedings. Maun, Botswana, 9-12 March, 1999.

17. Chon, K. and Maier, T. (2010). Welcome to hospitality: an introduction. $3^{\text {rd }}$ Edition. Delmar: Cengage Learning.

18. Chu, Y. (2014). A review of studies on luxury hotels over the past two decades. Graduate Thesis and Dissertation, Iowa State University. Available at: http://lib.dr.iastate.edu/cgi/viewcontent.cgi?article=4920\&context=etd. Accessed on 22 April 2016.

19. Co, M.J.,Groenewald, J., Mitchell, B., Nayager, T., van Zyl, J., Visser, K., Train, W. and Emanual, B. (2006). Entrepreneurship: fresh perspectives. Cape Town: Pearson Prentice Hall.

20. Cooper, D. and Schindler, P. (2003). Business research methods. $8^{\text {th }}$ edition. Boston: McGraw Hill.

21. Cupido, C. (2002). Barriers to entrepreneurship in the Western Cape. Unpublished MTech dissertation, Cape Peninsula University of Technology, Cape Town.

22. Dlabay, L., Burrow, J. and Kleindl, B. (2009). Introduction to business. $7^{\text {th }}$ ed. Mason, OH: SouthWestern Cengage Learning.

23. Edeson, B. (2014). Hospitality tourism management strategies. New Delhi: Random Publications.

24. Enz, C.A. (2010). Hospitality strategic management. Concepts and Cases. $2^{\text {nd }}$ edition. Hoboken, New Jersey: John Wiley \& Sons.

25. Gillham, B. (2008). Developing a questionnaire. $2^{\text {nd }}$ Edition. London: Continuum international.

26. Gitman, L.J. (2009). Principles of managerial finance. $12^{\text {th }}$ edition. Boston MA: Pearson Prentice Hall.

27. Hatten, T.S. (2015). Small business management: entrepreneurship and beyond. $6^{\text {th }}$ ed. Boston: Cengage Learning.

28. Haralambos, M. (2005). Sociology: themes and perspectives. $6^{\text {th }}$ Edition. London: Harper Collins.

29. Hisrich, R.D., Peters, M.P. and Shepherd, D.A. (2010). Entrepreneurship. $8^{\text {th }}$ edition. New York: McGraw-Hill.

30. ILO. (2014). Sustainable enterprises: creating more and better jobs. International labour organization, Geveva. Available at: www.ilo.org/sustainable-enterprises. Accessed on 20 July 2016.

31. Kauffmann, C. (2005). Financing SMEs in Africa. A joint publication of the African Development Bank and the OECD Development Centre. Policy Insights No 7, May. Available at: https://www.oecd.org/dev/34908457.pdf. Accessed on 7 June 2016.

32. Kumar, R. (2014). Research methodology: a step-by-step guide for beginners. $4^{\text {th }}$ edition. London: Sage.

33. Kurakto, D.F and Hodgetts, R.M. (2007). Entrepreneurship: theory, process, practice. $7^{\text {th }}$ ed. Mason, OH: Thomson.

34. Lamb, C.H., Hair, J.Jr., McDaniel, C., Boshoff, C. and Terblanche, N.S. (2008). Marketing. $3^{\text {rd }}$ ed. Cape Town: Oxford University Press.

35. Mahadea, D. and Youngleson, J. (2013). Entrepreneurship and small business management. Cape Town: Pearson Education.

36. Malhotra, N. and Birks, D. (2003). Marketing research: an applied approach. $2^{\text {nd }}$ ed. Harlow: Prentice Hall.

37. Marx, J., Swardt, C., Smith, M.B. and Erasmus, P. (2009). Financial management. $3^{\text {rd }}$ edition, Cape Town: Pearson Education.

38. Matthews, J. and Dennis, J. (2003). Lessons from the edge: survival skills for starting and growing a company. Oxford: Oxford University Press.

39. McDonald, D., Mashike, L. and Golden, C. (1999). The Lives and Times of African Migrants and Immigrants in Post Apartheid South Africa, Southern African Migration Project (SAMP). Migration Policy Series, (13), pp. 1-33.

40. McEwen, T. (2008). Environmental scanning and organizational learning in entrepreneurial ventures, Entrepreneurial Executive, 13, pp. 1-16.

41. McIntyre, R.J. and Alon, I. (2005). Business and Management Education in transitioning and developing countries: a handbook. Amonk, NY: M.E. Sharpe.

42. Nieman, G. and Nieuwenhuizen, C. (2009). Entrepreneurship: a South African perspective. $2^{\text {nd }}$ ed. Pretoria: Van Schaik.

43. Nieman, G. and Nieuwenhuizen, C. (2013). Entrepreneurship: a South African perspective. $3^{\text {rd }}$ ed. Pretoria: Van Schaik.

44. Pride, W. and Ferrell, O.C. (2010). Marketing. $15^{\text {th }}$ ed. Mason, OH: South-Western Cengage Learning.

45. Raosoft sample size calculator. Available at: http://www.raosoft.com/samplesize.html. Accessed on 20 June 2015.

46. Smart Opportunity. (2008). Available at: http://www.nedadmin.co.za/index.php?option=com_ content\&view=article\&id=44\&Itemid=57, What is Enterprise Development?. Accessed on 19 June 2012.

47. Stokes, D., Wilson, N. and Mador, M. (2010). Entrepreneurship. London: Cengage Learning.

48. Tengeh, R.K., Ballard, H. and Slabbert, A. (2011). A framework for acquiring the resources vital for the start-up of a business in South Africa: an African immigrant's perspective, European Journal of Social Sciences, 23 (3), pp. $362-381$.

49. Timmons, J.A. (1999). New venture creation: entrepreneurship for the $21^{\text {st }}$ century. $5^{\text {th }}$ ed. Homewood IL: McGraw Hill.

50. Walker, J.R. and Miller, J.E. (2010). Supervision in the hospitality industry. Leading Human Resources. $6^{\text {th }}$ ed. Hoboken, New Jersey: John Wiley.

51. Wang, G. (2009). Organizational and cross-cultural challenges facing expatriate hotel managers in China. Cape Town: Cape Peninsula University of Technology.

52. Wickham, P.A. (2004). Strategic entrepreneurship. $3^{\text {rd }}$ ed. Harlow: Financial Times \& Prentice Hall.

53. Wennekers, A.R.M. and Thurik, A.R. (1999). Linking entrepreneurship and economic growth, Small Business Economics, 13, pp. 27-55. 